\title{
Recent advances in antithrombotic therapy after acute coronary syndrome
}

\author{
Alexis Matteau MD MSc, Deepak L. Bhatt MD MPH
}

A cute coronary syndrome is a broad category of coronary heart disease that ranges from unstable angina to ST elevation myocardial infarction (MI). Its initial evaluation relies heavily on rapid triage according to the electrocardiogram and cardiac biomarkers.

The cornerstone of treatment for ST elevation MI is rapid reperfusion, which can be achieved either by fibrinolysis or primary percutaneous coronary intervention (PCI). ${ }^{1,2}$ When available, PCI is preferred if it can be achieved within 120 minutes of first medical contact, because it has been shown to reduce death, nonfatal MI or stroke. ${ }^{3}$ This strategy is also preferred if the MI is associated with high-risk features such as shock or heart failure, or if contraindications to fibrinolytics are present. ${ }^{4}$ The need for revascularization in the management of non-ST elevation acute coronary syndrome relies on risk stratification, which is based on risk factors, clinical presentation, electrocardiogram and cardiac biomarkers. An early invasive strategy with cardiac catheterization within the first 24-48 hours is preferred for patients with an unstable clinical condition and those at high risk of a serious outcome, because this strategy has been shown to reduce the long-term rate of death or nonfatal MI. ${ }^{5}$

\section{Box 1: Evidence used in this review}

We searched MEDLINE from Mar. 1, 2003, to Mar. 31, 2013, for randomized controlled trials with the following terms (alone or in combination): acute coronary syndrome, myocardial infarction, unstable angina, antiplatelet, anticoagulant, antithrombotic, aspirin, clopidogrel, prasugrel, ticagrelor, cangrelor, glycoprotein Ilb/llla inhibitors, heparin, enoxaparin, fondaparinux, bivalirudin, warfarin, dabigatran, rivaroxaban and apixaban. After screening the titles and abstracts, we retrieved and reviewed full articles. We also reviewed references of all articles. We used relevant guidelines from the American College of Cardiology and the American Heart Association, and drug labels from the US Food and Drug Administration and Health Canada.
This review will focus on recent advances in antiplatelet and anticoagulant agents used in the pharmacologic treatment of acute coronary syndrome. We included only the highest level of evidence, either large randomized control trials (RCTs) or meta-analyses of RCTs (Box 1).

\section{How should acetylsalicylic acid be given in acute coronary syndrome?}

Competing interests: See end of article for competing interests.

This article has been peer reviewed.

Correspondence to: Deepak Bhatt, dlbhattmd@ post.harvard.edu

CMAJ 2014. DOI:10.1503 /cmaj.130506
Acetylsalicylic acid (ASA) reduces platelet aggregation. ${ }^{6}$ Clinicians usually face 2 options when discharging patients: using either lowdose $(\leq 100 \mathrm{mg} / \mathrm{d})$ or high-dose $(\geq 300 \mathrm{mg} / \mathrm{d})$ ASA. A dedicated RCT on ASA dose, the CURRENT-OASIS 7 (Clopidogrel and Aspirin Optimal Dose Usage to Reduce Recurrent Events-Seventh Organization to Assess Strategies in Ischemic Syndromes) trial, showed that low-dose and high-dose ASA are associated with similar rates of cardiovascular death, MI or stroke at 30 days (hazard ratio [HR] 0.97, 95\% confidence interval [CI] 0.86-1.09). ${ }^{7}$ Multiple substudies of recent large RCTs of dual antiplatelet therapy have shown similar efficacy and lower rates of bleeding for low-dose compared with higher-dose ASA. ${ }^{7-12}$

\section{KEY POINTS}

- Potent newer-generation adenosine diphosphate receptor antagonists (prasugrel and ticagrelor) reduce major cardiovascular events in comparison with clopidogrel but are also associated with an increase in major bleeding.

- Use of glycoprotein Ilb/IIla inhibitors is mostly limited to the catheterization laboratory setting for procedural complications.

- Patients undergoing invasive management should receive intravenous unfractionated heparin, preferably with bivalirudin at the time of percutaneous coronary intervention.

- Patients receiving medical management (including those receiving fibrinolytics) should be given either enoxaparin or fondaparinux subcutaneously.

- In general, full dose oral anticoagulants are not indicated after acute coronary syndrome and warfarin should be the preferred agent in patients with other indications for anticoagulation such as atrial fibrillation or thromboembolic disease. 


\section{What additional antiplatelet therapy should be given?}

In addition to ASA, patients with acute coronary syndrome benefit from further inhibition of platelet aggregation by adenosine diphosphate (ADP) P2Y12 receptor antagonists. Until recently, only 2 agents were available: clopidogrel and ticlopidine, with ticlopidine usually reserved for patients with intolerance to clopidogrel. Major advances were made to antiplatelet therapy with the approval of 2 new agents, prasugrel and ticagrelor, which both have a more rapid, predictable and potent antiplatelet effect than clopidogrel (Table 1).

\section{Clopidogrel}

Clopidogrel has been extensively studied and has a class I recommendation (i.e., evidence or general agreement that treatment is useful and effective) for 1 year of treatment irrespective of invasive or conservative management of acute coronary syndrome. ${ }^{13-17}$ In situations where rapid onset of action is needed, a 600-mg loading dose of clopidogrel was shown to be faster acting than the usual 300mg loading dose ${ }^{18}$ Researchers attempted to address clopidogrel hyporesponsiveness by testing a double-dosing regimen during the first week in the CURRENT-OASIS 7 trial. $^{7}$ This regimen was not associated with a decrease in major cardiovascular events in the overall cohort; however, in the subgroup of patients who underwent PCI, major cardiovascular events at 30 days decreased from $4.5 \%$ to $3.9 \%$ (HR $0.86,95 \%$ CI $0.74-0.99$ ) with an increase in severe bleeding from $1.1 \%$ to $1.6 \%$ (HR 1.41, 95\% CI 1.09-1.83)..$^{12}$ Observational studies also raised the possibility that a drug-drug interaction with proton pump inhibitors might partially explain the variability in responsiveness to clopidogrel.$^{19,20}$ However, the only RCT that tested the addition of omeprazole among patients receiving ASA and clopidogrel, COGENT (the Clopidogrel and the Optimization of Gastrointestinal Events Trial), showed no difference in major cardiovascular events at 6 months. ${ }^{21}$

\section{Prasugrel}

In TRITON-TIMI 38 (Trial to Assess Improvement in Therapeutic Outcomes by Optimizing Platelet Inhibition with Prasugrel-Thrombolysis in Myocardial Infarction 38), researchers studied the use of prasugrel among patients with acute coronary syndrome who were undergoing PCI. The trial showed that major cardiovascular events were reduced from $12.1 \%$ to $9.9 \%$ (HR $0.81,95 \%$ CI 0.73-0.90) compared with clopidogrel, with an increase in major bleeding related to noncardiac surgery from $1.8 \%$ to $2.4 \%$ (HR $1.32,95 \% \mathrm{CI}$ $1.03-1.68) .^{22}$ Subsequent post hoc analyses of the trial identified 1 subgroup that was harmed by prasugrel (patients with prior transient ischemic attack or stroke) and 2 subgroups for which net benefit was less likely (patients aged $>75 \mathrm{yr}$ and those weighing $<60 \mathrm{~kg}$ ). The TRILOGY ACS (Targeted Platelet Inhibition to Clarify the Optimal Strategy

Table 1: Adenosine diphosphate receptor antagonists

\begin{tabular}{|c|c|c|c|c|}
\hline Agent & Timing & Dose & Duration & $\begin{array}{l}\text { Time required for } \\
\text { discontinuation before } \\
\text { cardiac surgery }\end{array}$ \\
\hline Ticlopidine & At presentation & $\begin{array}{l}\text { LD: } 500 \mathrm{mg} \\
\text { MD: } 250 \mathrm{mg} \text { twice } \\
\text { daily }\end{array}$ & $1 \mathrm{yr}$ post-ACS & $5 d$ \\
\hline Clopidogrel & At presentation & $\begin{array}{l}\text { LD: } 300-600 \text { mg } \dagger \\
\text { MD: } 75 \text { mg daily }\end{array}$ & $1 \mathrm{yr}$ post-ACS & $5 d$ \\
\hline Prasugrel & $\begin{array}{l}\text { At time of } \mathrm{PCl} \text { or at } \\
\text { presentation for } \\
\text { STEMI managed with } \\
\text { primary } \mathrm{PCl}\end{array}$ & $\begin{array}{l}\text { LD: } 60 \mathrm{mg} \\
\text { MD: } 10 \mathrm{mg} \text { daily } \neq\end{array}$ & $1 \mathrm{yr}$ post-ACS & $7 d$ \\
\hline Ticagrelor & $\begin{array}{l}\text { At presentation (not } \\
\text { with thrombolytics) }\end{array}$ & $\begin{array}{l}\text { LD: } 180 \mathrm{mg} \\
\text { MD: } 90 \mathrm{mg} \text { twice } \\
\text { daily }\end{array}$ & $1 \mathrm{yr}$ post-ACS & $5 d$ \\
\hline Cangrelor* & At time of $\mathrm{PCl}$ & $\begin{array}{l}30 \mu \mathrm{g} / \mathrm{kg} \mathrm{IV} \text { bolus, } \\
\text { then } 4 \mu \mathrm{g} / \mathrm{kg} / \mathrm{min} \\
\text { infusion }\end{array}$ & $\begin{array}{l}2 \mathrm{~h} \text { or duration } \\
\text { of procedure }\end{array}$ & $1 \mathrm{~h}$ \\
\hline \multicolumn{5}{|c|}{$\begin{array}{l}\text { Note: } \mathrm{ACS}=\text { acute coronary syndrome, IV = intravenous, } \mathrm{LD}=\text { loading dose, } \mathrm{MD}=\text { maintenance dose, } \mathrm{PCl}=\text { percutaneous } \\
\text { coronary intervention, STEMI = ST elevation myocardial infarction. } \\
\text { *Not approved by Health Canada or the US Food and Drug Administration at the time of writing. } \\
\text { IIn patients going to the catheterization laboratory within } 24 \text { hours, a } 600-\mathrm{mg} \mathrm{LD} \text { is preferred. } \\
\text { fConsider prasugrel } 5 \mathrm{mg} \text { daily in patients who weigh less than } 60 \mathrm{~kg} \text {. }\end{array}$} \\
\hline
\end{tabular}


to Medically Manage Acute Coronary Syndromes) RCT, which evaluated medical therapy with prasugrel among patients with acute coronary syndrome who were not undergoing revascularization, showed no clear benefits compared with clopidogrel..$^{23} \mathrm{~A}$ subgroup analysis of TRILOGY ACS suggested that there may have been benefits of more potent antiplatelet therapy in those with angiographically confirmed coronary artery disease. ${ }^{24}$

\section{Ticagrelor}

The PLATO (Platelet Inhibition and Patient Outcomes) RCT found that ticagrelor significantly reduced major cardiovascular events from $11.7 \%$ to $9.8 \%$ (HR $0.84,95 \%$ CI 0.77-0.92) compared with clopidogrel, including a significant absolute decrease of $1.1 \%$ in vascular mortality. ${ }^{25}$ Rates of major bleeding related to noncardiac surgery were increased from $3.8 \%$ to $4.5 \%$ (HR 1.19 , 95\% CI 1.02-1.38). Because heterogeneity of ticagrelor effect by geographical region was linked to the ASA dose used concomitantly, it is indicated only in association with low-dose $\left(\leq 100 \mathrm{mg}\right.$ daily) ASA. ${ }^{26}$

\section{Cangrelor}

The recently published CHAMPION (Cangrelor versus Standard Therapy to Achieve Optimal Management of Platelet Inhibition) PHOENIX RCT evaluated cangrelor, an intravenous direct-acting ADP receptor antagonist with a short half-life. ${ }^{27}$ Among patients undergoing PCI who were not taking ADP receptor antagonists, cangrelor reduced major coronary events at 48 hours compared with placebo $(5.9 \%$ v. $4.7 \%$; odds ratio $0.78,95 \% \mathrm{CI}$ 0.66-0.93) without increasing severe bleeding events. A meta-analysis of the 3 CHAMPION trials confirmed these findings, including a reduction in stent thrombosis at 48 hours. ${ }^{28}$

\section{Recommendations for clinical practice}

Among patients with acute coronary syndrome who are not at high risk of bleeding who undergo PCI, either prasugrel or ticagrelor can be used. Ticagrelor decreases vascular mortality, can be used in patients with medically managed acute coronary syndrome and can be given in the emergency department as pretreatment, but it needs to be taken twice daily and can be associated with bradycardia (ventricular pauses $>3 \mathrm{~s}$ at 1 wk: $5.8 \%$ v. $3.6 \%$ with clopidogrel, $p=0.01$ ) and dyspnea ( $13.8 \%$ v. $7.8 \%$ with clopidogrel, $p<0.001){ }^{25}$ Clopidogrel is preferred for patients who are receiving fibrinolytics, and those in need of long-term anticoagulation and at higher risk of bleeding. In many regions, newer agents are not available or costs are increased compared with generic clopidogrel.

\section{What is the current role of glycoprotein Ilb/Illa receptor antagonists?}

Use of glycoprotein IIb/IIIa receptor antagonists has declined sharply in the last 5 years with the increasing use of pretreatment with ADP antagonists, the use of bivalirudin (a direct thrombin inhibitor) at the time of PCI and the emerging role of newer molecules. ${ }^{16,17,29}$ This class of drug, which includes abciximab, eptifibatide and tirofiban, inhibits platelet aggregation by preventing binding of fibrinogen between platelets via the glycoprotein IIb/IIIa receptors. These agents are still indicated for patients who did not receive dual antiplatelet therapy, for patients who have recurrent symptoms despite dual antiplatelet therapy, or at the time of PCI for patients with ST elevation MI who are receiving intravenous unfractionated heparin. Pretreatment with these drugs before primary PCI in ST elevation MI was not associated with benefit in terms of major cardiovascular events and increased bleeding complications. ${ }^{30-32}$ In contemporary practice, they are mostly given at the time of PCI in the event of procedural complications.

\section{What parenteral anticoagulation should be given?}

Four agents are commonly used in acute coronary syndrome: unfractionated heparin, enoxaparin, fondaparinux and bivalirudin. The first 3 are indirect agents, whereas bivalirudin is a direct inhibitor of thrombin. Intravenous unfractionated heparin is indicated in all scenarios of acute coronary syndrome, alone or in combination with glycoprotein IIb/IIIa inhibitors, and should be administered when the diagnosis is made. . $1,17,29^{-29}$

\section{Anticoagulation with medical or thrombolytic therapy}

Among patients receiving conservative treatment or fibrinolytics, all agents can be used except for bivalirudin, which has not been well studied in these settings (Table $2^{33-38}$ ). Both enoxaparin (relative risk [RR] $0.83,95 \% \mathrm{CI} 0.77-0.90$ ) and fondaparinux (RR $0.82,95 \%$ CI $0.66-1.02$ ) when used up to 8 days or until discharge were found to reduce major cardiac events in ST elevation MI compared with unfractionated heparin. ${ }^{33,35}$ An increase in major bleeding was present with enoxaparin (RR 1.53, 95\% CI 1.23-1.89). ${ }^{33}$ Head-tohead comparison of enoxaparin and fondaparinux was done in non-ST elevation acute coronary syndrome and showed that fondaparinux caused fewer 
Table 2: Major randomized controlled trials of parenteral anticoagulants, by medical and invasive management

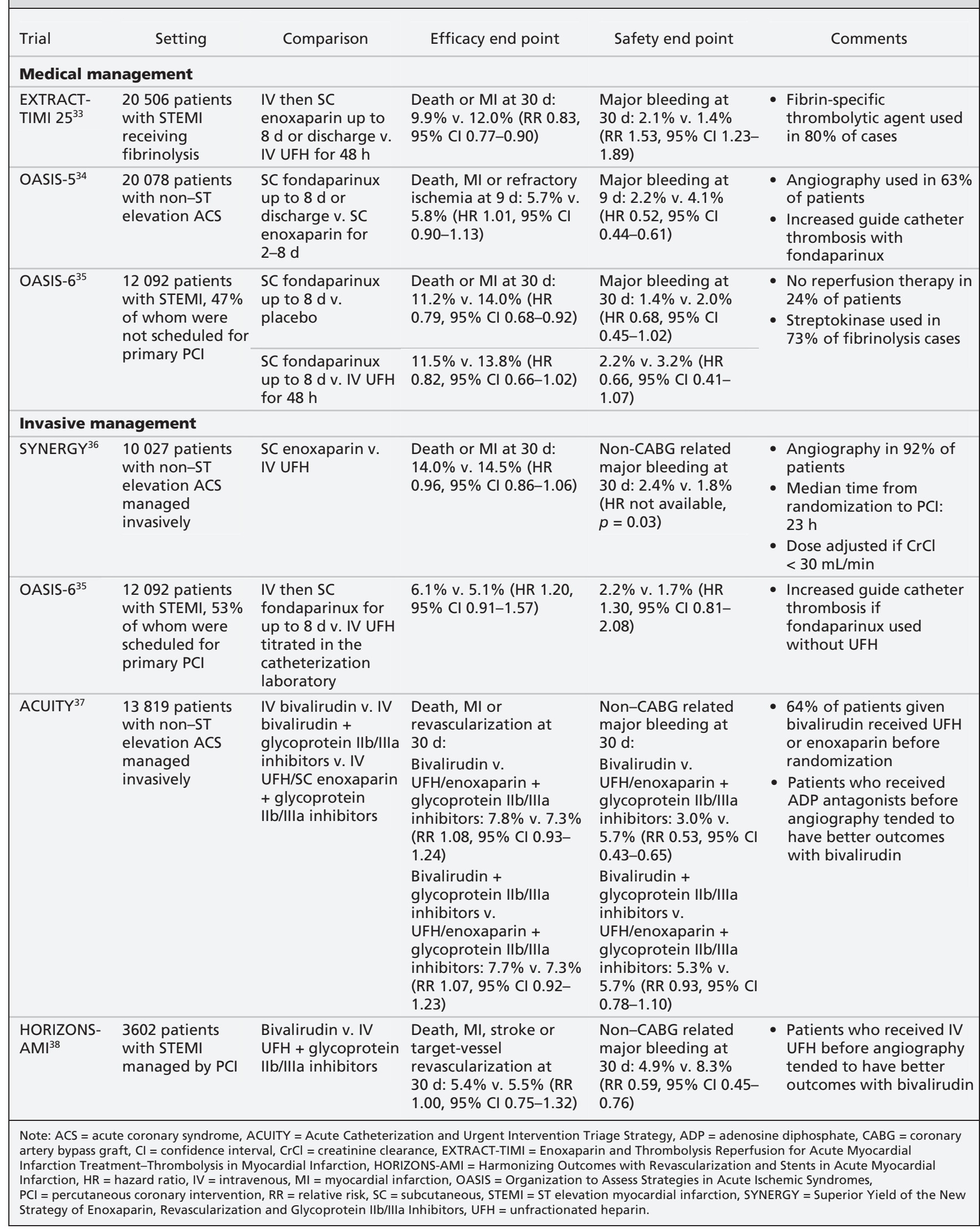


major bleeding events (HR 0.52, 95\% CI 0.44 0.61 ) without compromising efficacy. ${ }^{34}$

\section{Anticoagulation with invasive management}

Among patients receiving early invasive treatment or primary PCI, any of the agents can be considered (Table 2); however, fondaparinux when used alone is associated with catheter thrombosis. ${ }^{34,35}$ This phenomenon can be overcome with use of a bolus of unfractionated heparin during the procedure. Because of lack of efficacy and safety in the primary PCI arm of OASIS-6, fondaparinux is not recommended for ST elevation MI managed invasively. ${ }^{35}$ Enoxaparin appears to increase major bleeding complications when compared with unfractionated heparin in non-ST elevation acute coronary syndrome, largely related to patients who crossed over arms of treatment during a trial. ${ }^{36}$ Finally, bivalirudin was shown to reduce major bleeding episodes (HR 0.59, 95\% CI 0.45-0.76) compared with heparin plus glycoprotein IIb/IIIa inhibitors with similar rates of major cardiovascular events..$^{37,38}$ In subgroup analyses, patients who received pretreatment with clopidogrel and unfractionated heparin before angiography tended to have the best results with bivalirudin.

\section{Recommendations for clinical practice}

Patients receiving conservative treatment or fibrinolysis should receive either enoxaparin or fondaparinux because of ease of use and comparable efficacy. Data on enoxaparin in ST elevation MI appear to be stronger compared with fondaparinux and use should be encouraged, whereas fondaparinux should be a first option, if available, in non-ST elevation MI over enoxaparin because of its better safety.

Among patients receiving invasive treatment, intravenous unfractionated heparin should be given as soon as the diagnosis is made because this agent can be easily titrated in the catheterization laboratory; it avoids switching between enoxaparin and unfractionated heparin, which can be associated with an increase in bleeding; and it allows for bivalirudin use during PCI at the interventional cardiologist's discretion, based on ischemic and bleeding risk evaluation.

\section{Is there a role for oral anticoagulants after acute coronary syndrome?}

Observational studies have shown that duration of anticoagulation was inversely correlated to

Table 3: Major randomized controlled trials of oral anticoagulants

\begin{tabular}{|c|c|c|c|c|c|}
\hline Trial & Setting & Comparison & Efficacy & Safety & Comments \\
\hline APPRAISE- $2^{40}$ & $\begin{array}{l}\text { High-risk ACS } \\
\text { within the } \\
\text { previous } 7 \mathrm{~d} \text {, } \\
\text { treated with } \\
\text { ASA and } \\
\text { clopidogrel }\end{array}$ & $\begin{array}{l}\text { Apixaban } 5 \text { mg } \\
\text { twice daily } \mathrm{v} . \\
\text { placebo }\end{array}$ & $\begin{array}{l}\text { Cardiovascular death, MI or } \\
\text { ischemic stroke: } 7.5 \% \text { v. } \\
7.9 \% \text { (HR } 0.95,95 \% \mathrm{Cl} \\
0.80-1.11)\end{array}$ & $\begin{array}{l}\text { Major bleeding:* } \\
1.3 \% \text { v. } 0.5 \%(\mathrm{HR} \\
2.59,95 \% \mathrm{Cl} \\
1.50-4.46)\end{array}$ & $\begin{array}{l}\text { Prior stroke or } \\
\text { transient ischemic } \\
\text { attack: } 10 \% \text { of patients } \\
\text { - Stopped early owing } \\
\text { to lack of efficacy and } \\
\text { excess bleeding } \\
\text { (median exposure to } \\
\text { apixaban: } 175 \mathrm{~d} \text { ) }\end{array}$ \\
\hline \multirow[t]{5}{*}{$\begin{array}{l}\text { ATLAS ACS } \\
2 \text {-TIMI } 51^{41}\end{array}$} & \multirow[t]{5}{*}{$\begin{array}{l}\text { ACS within } \\
\text { the previous } \\
7 \mathrm{~d} \text {, treated } \\
\text { with ASA and } \\
\text { clopidogrel }\end{array}$} & \multirow[t]{5}{*}{$\begin{array}{l}\text { Rivaroxaban } \\
2.5 \mathrm{mg} \text { twice } \\
\text { daily v. } \\
\text { rivaroxaban } \\
5.0 \mathrm{mg} \text { twice } \\
\text { daily v. placebo }\end{array}$} & $\begin{array}{l}\text { Cardiovascular death, MI or } \\
\text { stroke: } \\
2.5 \mathrm{mg} \text { twice daily v. placebo: } \\
9.1 \% \text { v. } 10.7 \% \text { (HR } 0.84,95 \% \\
\text { Cl } 0.72-0.97 \text { ) }\end{array}$ & $\begin{array}{l}\text { Non-CABG } \\
\text { related major } \\
\text { bleeding:* } \\
2.5 \text { mg twice } \\
\text { daily v. placebo: }\end{array}$ & \multirow{5}{*}{$\begin{array}{l}\text { Patients with prior } \\
\text { stroke or transient } \\
\text { ischemic attack } \\
\text { excluded from trial if } \\
\text { receiving dual } \\
\text { antiplatelet therapy } \\
\text { - Mean duration of } \\
\text { study drug: } 13.1 \text { mo }\end{array}$} \\
\hline & & & $\begin{array}{l}5.0 \mathrm{mg} \text { v. placebo: } 8.8 \% \text { v. } \\
10.7 \% \text { (HR } 0.85,95 \% \mathrm{Cl} \\
0.73-0.98)\end{array}$ & $\begin{array}{l}1.8 \% \text { v. } 0.6 \% \\
(\mathrm{HR} 3.46,95 \% \mathrm{Cl} \\
2.08-5.77)\end{array}$ & \\
\hline & & & Cardiovascular death: & \multirow{3}{*}{$\begin{array}{l}5.0 \mathrm{mg} \mathrm{v} . \\
\text { placebo: } 2.4 \% \text { v. } \\
0.6 \% \text { (HR } 4.47 \\
95 \% \mathrm{Cl} 2.71-7.36)\end{array}$} & \\
\hline & & & $\begin{array}{l}2.5 \text { mg twice daily v. placebo: } \\
2.7 \% \text { v. } 4.1 \% \text { (HR } 0.66,95 \% \\
\text { Cl } 0.51-0.86)\end{array}$ & & \\
\hline & & & $\begin{array}{l}5.0 \mathrm{mg} \text { v. placebo: } 4.0 \% \mathrm{v} \text {. } \\
4.1 \% \text { (HR } 0.94,95 \% \mathrm{Cl} \\
0.75-1.20)\end{array}$ & & \\
\hline
\end{tabular}


presence of mural thrombus in anteroapical aneurysms, which is associated with systemic embolization. ${ }^{39}$ The addition of warfarin to dual antiplatelet therapy with clopidogrel is still indicated for 3 months after an anterior ST elevation MI with residual apical akinesis based on these data. ${ }^{17}$

Substantial progress has been made in the field of oral anticoagulants with new molecules that have more predictable antithrombotic effect and require less monitoring. Dabigatran, an oral direct thrombin inhibitor, has not been evaluated in any large RCT of acute coronary syndrome. Apixaban and rivaroxaban are oral direct factor $\mathrm{Xa}$ inhibitors that have been evaluated in acute coronary syndrome (Table $3^{40,41}$ ). The trial evaluating full-dose apixaban versus placebo was

\section{Box 2: Applying the results of this review in clinical practice (fictional cases)}

Scenario 1: A 55-year-old man with hypertension was brought to the emergency department with 60 minutes of crushing chest pain. An electrocardiogram obtained 5 minutes after arrival showed ST segment elevation in the anterior leads. He quickly received $325 \mathrm{mg}$ of acetylsalicylic acid (ASA), $180 \mathrm{mg}$ of ticagrelor and 4000 units of intravenous unfractionated heparin. He was then taken to the catheterization laboratory where angiography performed via the femoral artery showed an occluded left anterior descending coronary artery. A bolus of bivalirudin followed by an infusion was started, and percutaneous coronary intervention of his occluded coronary artery was performed with implantation of a drug-eluting stent without complication. The bivalirudin infusion was stopped at the end of the procedure, and the patient was admitted to hospital for 3 days. He was discharged home with ASA $80 \mathrm{mg}$ daily and ticagrelor $90 \mathrm{mg}$ twice daily, which he will take for 1 year.

Scenario 2: An 83-year-old woman with a prior stroke and a past episode of gastrointestinal bleeding was brought to the emergency department from her nursing home for shortness of breath and atypical chest discomfort. Her initial electrocardiogram showed T-wave inversion in the inferior leads, and a troponin test came back elevated. Because of her medical comorbidities and hemodynamic stability, conservative medical management was elected for her non-ST elevation myocardial infarction. Her ASA dosage was kept at $80 \mathrm{mg}$ daily, and a first dose of clopidogrel $300 \mathrm{mg}$ was given, followed by $75 \mathrm{mg}$ daily. She received $2.5 \mathrm{mg}$ of subcutaneous fondaparinux throughout her 6-day hospital stay without any recurrence of gastrointestinal bleeding. She was discharged back to her nursing home with ASA $80 \mathrm{mg}$ daily and clopidogrel $75 \mathrm{mg}$ daily for an intended duration of 12 months.

\section{Box 3: Gaps in knowledge}

- The optimal duration of dual antiplatelet therapy after acute coronary syndrome is uncertain, especially with the use of newer-generation drugeluting stents. Randomized trials are ongoing to evaluate longer and shorter durations than the standard 12 months (DAPT [ Dual Antiplatelet Therapy], ISAR-SAFE [Safety and Efficacy of Six Months Dual Antiplatelet Therapy After Drug-Eluting Stenting], OPTIMIZE [(Optimized Duration of Clopidogrel Therapy Following Treatment With the Endeavor Zotarolimus-Eluting Stent in the Real World Clinical Practice]).

- The role of yet unapproved drugs, such as intravenous adenosine diphosphate receptor antagonists and low-dose oral anticoagulants, is still undefined.

- Defining new factors associated with antiplatelet response has not yet allowed personalization of antiplatelet therapy. stopped early owing to a lack of benefit and an increased risk of major bleeding (HR 2.59, $95 \%$ CI $1.50-4.46) .{ }^{40}$ Very low-dose rivaroxaban (2.5 mg twice daily) given within 7 days of acute coronary syndrome, compared with placebo, decreased the incidence of major cardiac events, including mortality $(9.1 \%$ v. $10.7 \%$; HR $0.84,95 \%$ CI $0.72-0.97$ ), at the expense of an increase in major bleeding (1.8\% v. $0.6 \%$; HR 3.46 , 95\% CI 2.08-5.77). ${ }^{41}$ The 5-mg twicedaily dose was also tested and showed similar results for the ischemic component, but bleeding risk was greater. ${ }^{41}$

Besides the recommendation of a short course of warfarin in patients with post-MI apical akinesis, there is no indication for full-dose oral anticoagulation after acute coronary syndrome. Among patients with other indications for anticoagulation such as atrial fibrillation or thromboembolic process, warfarin still appears to be the preferable drug to use because full-dose newer anticoagulants either have no data involving patients receiving dual antiplatelet therapy or are known to increase major bleeding without having an antidote in case of adverse events.

\section{Remaining challenges}

Box 2 provides 2 examples of when and how to use antiplatelet agents and anticoagulants in acute coronary syndrome. Although therapeutic options have evolved substantially in recent years, there are still many questions to answer (Box 3). Dual antiplatelet therapy after acute coronary syndrome is indicated for 1 year, but its optimal duration, especially among patients who receive newer-generation drug-eluting stents, is uncertain. ${ }^{42-46}$ Several trials are underway testing shorter and longer durations of dual antiplatelet therapy. ${ }^{47-49}$ Attempts to personalize therapy with the use of platelet function testing or genetic testing to adjust clopidogrel dose have been unsuccessful..$^{50,51}$ Even after controlling for known factors that affect drug metabolism and compliance, variability in clopidogrel response is still large. ${ }^{52}$ Newer antiplatelet agents may address this problem, but increased costs, lack of widespread availability, increase in bleeding and unknown effect when combined with oral anticoagulants will mean that clopidogrel continues to be prescribed for a substantial proportion of patients.

\section{References}

1. Armstrong PW, Gershlick AH, Goldstein P, et al. Fibrinolysis or primary PCI in ST-segment elevation myocardial infarction. N Engl J Med 2013;368:1379-87.

2. Bhatt DL. Timely PCI for STEMI - still the treatment of choice. N Engl J Med 2013;368:1446-7.

3. Keeley EC, Boura JA, Grines CL. Primary angioplasty versus intravenous thrombolytic therapy for acute myocardial infarc- 
tion: a quantitative review of 23 randomised trials. Lancet 2003; 361:13-20.

4. Hochman JS, Sleeper LA, Webb JG, et al. Early revascularization in acute myocardial infarction complicated by cardiogenic shock. SHOCK investigators. Should we emergently revascularize occluded coronaries for cardiogenic shock. N Engl J Med 1999 341:625-34.

5. Fox KA, Clayton TC, Damman P, et al. Long-term outcome of a routine versus selective invasive strategy in patients with nonST-segment elevation acute coronary syndrome a meta-analysis of individual patient data. J Am Coll Cardiol 2010;55:2435-45.

6. Patrono C, Garcia Rodriguez LA, Landolfi R, et al. Low-dose aspirin for the prevention of atherothrombosis. N Engl J Med 2005 353:2373-83.

7. CURRENT-OASIS 7 Investigators, Mehta SR, Bassand JP, et al. Dose comparisons of clopidogrel and aspirin in acute coronary syndromes. N Engl J Med 2010;363:930-42.

8. Peters RJ, Mehta SR, Fox KA, et al. Effects of aspirin dose when used alone or in combination with clopidogrel in patients with acute coronary syndromes: observations from the clopidogrel in unstable angina to prevent recurrent events (CURE) study. Circulation 2003;108:1682-7.

9. Jolly SS, Pogue J, Haladyn K, et al. Effects of aspirin dose on ischaemic events and bleeding after percutaneous coronary intervention: insights from the PCI-CURE study. Eur Heart J 2009; 30:900-7.

10. Steinhubl SR, Bhatt DL, Brennan DM, et al. Aspirin to prevent cardiovascular disease: the association of aspirin dose and clopidogrel with thrombosis and bleeding. Ann Intern Med 2009;150:379-86.

11. Yu J, Mehran R, Dangas GD, et al. Safety and efficacy of highversus low-dose Aspirin after primary percutaneous coronary intervention in ST-segment elevation myocardial infarction: the HORIZONS-AMI (harmonizing outcomes with revascularization and stents in acute myocardial infarction) trial. JACC Cardiovasc Interv 2012;5:1231-8.

12. Mehta SR, Tanguay JF, Eikelboom JW, et al. Double-dose versus standard-dose clopidogrel and high-dose versus low-dose aspirin in individuals undergoing percutaneous coronary intervention for acute coronary syndromes (CURRENT-OASIS 7): a randomised factorial trial. Lancet 2010;376:1233-43.

13. Yusuf S, Zhao F, Mehta SR, et al. Effects of clopidogrel in addition to aspirin in patients with acute coronary syndromes without ST-segment elevation. N Engl J Med 2001;345:494-502.

14. Chen ZM, Jiang LX, Chen YP, et al. Addition of clopidogrel to aspirin in 45852 patients with acute myocardial infarction: randomised placebo-controlled trial. Lancet 2005;366:1607-21.

15. Sabatine MS, Cannon CP, Gibson CM, et al. Addition of clopidogrel to aspirin and fibrinolytic therapy for myocardial infarction with ST-segment elevation. N Engl J Med 2005;352:1179-89.

16. 2012 Writing Committee Members, Jneid H, Anderson JL, Wright RS, et al. 2012 ACCF/AHA focused update of the guideline for the management of patients with unstable angina/nonST-elevation myocardial infarction (updating the 2007 guideline and replacing the 2011 focused update): a report of the American College of Cardiology Foundation/American Heart Association Task Force on Practice Guidelines. Circulation 2012;126: 875-910.

17. O'Gara PT, Kushner FG, Ascheim DD, et al. 2013 ACCF/AHA guideline for the management of ST-elevation myocardial infarction: a report of the American College of Cardiology Foundation/American Heart Association Task Force on Practice Guidelines. Circulation 2013;127:e362-425.

18. Montalescot G, Sideris G, Meuleman C, et al. A Randomized comparison of high clopidogrel loading doses in patients with non-ST-segment elevation acute coronary syndromes: the ALBION (Assessment of the Best Loading Dose of Clopidogrel to Blunt Platelet Activation, Inflammation and Ongoing Necrosis) trial. J Am Coll Cardiol 2006;48:931-8.

19. Ho PM, Maddox TM, Wang L, et al. Risk of adverse outcomes associated with concomitant use of clopidogrel and proton pump inhibitors following acute coronary syndrome. JAMA 2009;301: 937-44.

20. Juurlink DN, Gomes T, Ko DT, et al. A population-based study of the drug interaction between proton pump inhibitors and clopidogrel. CMAJ 2009;180:713-8.

21. Bhatt DL, Cryer BL, Contant CF, et al. Clopidogrel with or without omeprazole in coronary artery disease. N Engl J Med 2010; 363:1909-17.

22. Wiviott SD, Braunwald E, McCabe $\mathrm{CH}$, et al. Prasugrel versus clopidogrel in patients with acute coronary syndromes. $N$ Engl J Med 2007;357:2001-15

23. Roe MT, Armstrong PW, Fox KA, et al. Prasugrel versus clopidogrel for acute coronary syndromes without revascularization. N Engl J Med 2012;367:1297-309.
24. Wiviott SD, White HD, Ohman EM, et al. Prasugrel versus clopidogrel for patients with unstable angina or non-ST-segment elevation myocardial infarction with or without angiography: a secondary, prespecified analysis of the TRILOGY ACS trial. Lancet 2013;382:605-13

25. Wallentin L, Becker RC, Budaj A, et al. Ticagrelor versus clopidogrel in patients with acute coronary syndromes. $N$ Engl $\mathrm{J} \mathrm{Med}$ 2009;361:1045-57.

26. Mahaffey KW, Wojdyla DM, Carroll K, et al. Ticagrelor compared with clopidogrel by geographic region in the platelet inhibition and patient outcomes (PLATO) trial. Circulation 2011;124:544-54.

27. Bhatt DL, Stone GW, Mahaffey KW, et al. Effect of platelet inhibition with cangrelor during PCI on ischemic events. $N$ Engl J Med 2013;368:1303-13.

28. Steg PG, Bhatt DL, Hamm CW, et al. Effect of cangrelor on periprocedural outcomes in percutaneous coronary interventions: a pooled analysis of patient-level data. Lancet 2013 Sept. 2. [Epub ahead of print]

29. Anderson JL, Adams CD, Antman EM, et al. ACC/AHA 2007 guidelines for the management of patients with unstable angina/non ST-elevation myocardial infarction: a report of the American College Of Cardiology/American Heart Association Task Force on Practice Guidelines (writing committee to revise the 2002 guidelines for the management of patients with unstable angina/non STelevation myocardial infarction): developed in collaboration with the American College of Emergency Physicians, the Society for Cardiovascular Angiography and Interventions, and the Society of Thoracic Surgeons: endorsed by the American Association of Cardiovascular and Pulmonary Rehabilitation and the Society for Academic Emergency Medicine. Circulation 2007;116:e148-304.

30. Ellis SG, Tendera M, de Belder MA, et al. Facilitated PCI in patients with ST-elevation myocardial infarction. $N$ Engl $\mathrm{J} \mathrm{Med}$ 2008:358:2205-17.

31. Van't Hof AW, Ten Berg J, Heestermans T, et al. Prehospital initiation of tirofiban in patients with ST-elevation myocardial infarction undergoing primary angioplasty (ON-TIME 2): a multicentre, double-blind, randomised controlled trial. Lancet 2008; 372:537-46.

32. Giugliano RP, White JA, Bode C, et al. Early versus delayed, provisional eptifibatide in acute coronary syndromes. $N$ Engl $\mathrm{J} \mathrm{Med}$ 2009;360:2176-90.

33. Antman EM, Morrow DA, McCabe $\mathrm{CH}$, et al. Enoxaparin versus unfractionated heparin with fibrinolysis for ST-elevation myocardial infarction. N Engl J Med 2006;354:1477-88.

34. Fifth Organization to Assess Strategies in Acute Ischemic Syndromes Investigators, Yusuf S, Mehta SR, Chrolavicius S, et al. Comparison of fondaparinux and enoxaparin in acute coronary syndromes. N Engl J Med 2006;354:1464-76.

35. Yusuf S, Mehta SR, Chrolavicius S, et al. Effects of fondaparinux on mortality and reinfarction in patients with acute STsegment elevation myocardial infarction: the OASIS-6 randomized trial. JAMA 2006;295:1519-30.

36. Ferguson JJ, Califf RM, Antman EM, et al. Enoxaparin vs unfractionated heparin in high-risk patients with non-ST-segment elevation acute coronary syndromes managed with an intended early invasive strategy: primary results of the SYNERGY randomized trial. JAMA 2004;292:45-54.

37. Stone GW, McLaurin BT, Cox DA, et al. Bivalirudin for patients with acute coronary syndromes. N Engl J Med 2006:355:2203-16.

38. Stone GW, Witzenbichler B, Guagliumi G, et al. Bivalirudin during primary PCI in acute myocardial infarction. N Engl J Med 2008; 358:2218-30.

39. Reeder GS, Lengyel M, Tajik AJ, et al. Mural thrombus in left ventricular aneurysm: incidence, role of angiography, and relation between anticoagulation and embolization. Mayo Clin Proc 1981; 56:77-81.

40. Alexander JH, Lopes RD, James S, et al. Apixaban with antiplatelet therapy after acute coronary syndrome. $N$ Engl $\mathrm{J} \mathrm{Med}$ 2011;365:699-708.

41. Mega JL, Braunwald E, Wiviott SD, et al. Rivaroxaban in patients with a recent acute coronary syndrome. N Engl J Med 2012; 366:9-19.

42. Park SJ, Park DW, Kim YH, et al. Duration of dual antiplatelet therapy after implantation of drug-eluting stents. $N$ Engl J Med 2010;362:1374-82.

43. Gwon HC, Hahn JY, Park KW, et al. Six-month versus 12month dual antiplatelet therapy after implantation of drugeluting stents: the efficacy of xience/promus versus cypher to reduce late loss after stenting (EXCELLENT) randomized, multicenter study. Circulation 2012;125:505-13.

44. Valgimigli M, Campo G, Monti M, et al. Short- versus longterm duration of dual-antiplatelet therapy after coronary stenting: a randomized multicenter trial. Circulation 2012;125: 2015-26. 
45. Bhatt DL. Examination of new drug-eluting stents - top of the class! Lancet 2012;380:1453-5.

46. Sabate M, Cequier A, Iniguez A, et al. Everolimus-eluting stent versus bare-metal stent in ST-segment elevation myocardia infarction (EXAMINATION): 1 year results of a randomised controlled trial. Lancet 2012;380:1482-90.

47. Byrne RA, Schulz S, Mehilli J, et al. Rationale and design of a randomized, double-blind, placebo-controlled trial of 6 versus 12 months clopidogrel therapy after implantation of a drugeluting stent: The Intracoronary Stenting And Antithrombotic Regimen: Safety And Efficacy Of 6 Months Dual Antiplatelet Therapy After Drug-Eluting Stenting (ISAR-SAFE) study. Am Heart J 2009;157:620-4.e2.

48. Mauri L, Kereiakes DJ, Normand SL, et al. Rationale and design of the dual antiplatelet therapy study, a prospective, multicenter, randomized, double-blind trial to assess the effectiveness and safety of 12 versus 30 months of dual antiplatelet therapy in subjects undergoing percutaneous coronary intervention with either drug-eluting stent or bare metal stent placement for the treatment of coronary artery lesions. Am Heart J 2010;160:1035-41, 1041.e1.

49. Feres F, Costa RA, Bhatt DL, et al. Optimized duration of clopidogrel therapy following treatment with the endeavor zotarolimus-eluting stent in real-world clinical practice (OPTIMIZE) trial: rationale and design of a large-scale, randomized, multicenter study. Am Heart J 2012;164:810-6.e3.

50. Price MJ, Berger PB, Teirstein PS, et al. Standard- v. high-dose clopidogrel based on platelet function testing after percutaneous coronary intervention: the gravitas randomized trial [published erratum in JAMA 2011;305:2174]. JAMA 2011;305:1097-105.

51. Collet JP, Cuisset T, Range G, et al. Bedside monitoring to adjust antiplatelet therapy for coronary stenting. $N$ Engl $\mathrm{J} \mathrm{Med}$ 2012;367:2100-9.

52. Frelinger AL III, Bhatt DL, Lee RD, et al. Clopidogrel pharmacokinetics and pharmacodynamics vary widely despite exclusion or control of polymorphisms (CYP2C19, ABCB1, PON1), noncompliance, diet, smoking, co-medications (including proton pump inhibitors), and pre-existent variability in platelet function. J Am Coll Cardiol 2013;61:872-9.

Competing interests: Deepak Bhatt discloses the following relationships: advisory board: Elsevier Practice Update Cardiology, Medscape Cardiology, Regado Biosciences; board of directors: Boston VA Research Institute, Society of Cardiovascular Patient Care; chair: American Heart Association Get With The Guidelines Steering Committee; honoraria: Ameri- can College of Cardiology (editor, Clinical Trials, CardioSource), Belvoir Publications (editor-in-chief, Harvard Heart Letter), Duke Clinical Research Institute (clinical trial steering committees), Population Health Research Institute (clinical trial steering committee), Slack Publications (chief medical editor, Cardiology Today's Intervention), WebMD (continuing medical education steering committees); other: senior associate editor, Journal of Invasive Cardiology; data monitoring committees: Duke Clinical Research Institute; Harvard Clinical Research Institute; Mayo Clinic; Population Health Research Institute; research grants: Amarin, AstraZeneca, Bristol-Myers Squibb, Eisai, Ethicon, Medtronic, Sanofi-Aventis, The Medicines Company; unfunded research: FlowCo, PLx Pharma, Takeda; served or serves as co-chair of CHAMPION PCI, CHAMPION PLATFORM and CHAMPION PHOENIX, as chair of COGENT, on the executive committee of ATLAS ACS 2-TIMI 51 (AntiXa Therapy to Lower Cardiovascular Events in Addition to Standard Therapy in Subjects with Acute Coronary Syndrome-Thrombolysis in Myocardial Infarction) and PEGASUS-TIMI 54 (Prevention of Cardiovascular Events [e.g., Death From Heart or Vascular Disease, Heart Attack, or Stroke] in Patients With Prior Heart Attack Using Ticagrelor Compared to Placebo on a Background of Aspirin-Thrombolysis in Myocardial Infarction), as principal investigator of CHARISMA (Clopidogrel for High Atherothrombotic Risk and Ischemic Stabilization, Management, and Avoidance), on the steering committee of APPRAISE-2 (Apixaban for Prevention of Acute Ischemic Events 2), COMPASS (Cardiovascular Outcomes for People using Anticoagulation Strategies) and TRILOGY-ACS (Targeted Platelet Inhibition to Clarify the Optimal Strategy to Medically Manage Acute Coronary Syndromes). No competing interests declared by Alexis Matteau.

Affiliations: VA Boston Healthcare System, Brigham and Women's Hospital, and Harvard Medical School, Boston, Mass.

Contributors: Both authors contributed to the conception and design of the article, and the interpretation of data. Alexis Matteau drafted the article, which Deepak Bhatt revised. Both authors gave final approval of the version submitted for publication. 